\title{
Talents Cultivation Mode of Integrated Innovation for Information Technology and Law
}

\author{
Shan Meijing ${ }^{1, a^{*}}$ \\ ${ }^{1}$ Department of Information Science and Technology, \\ East China University of Political Science and Law, Shanghai, 201620, China \\ ashanmeijing@ecupl.edu.cn
}

Keywords: Computer competition; Computer basic course; Law character; Talent cultivation mode

\begin{abstract}
In the current new situation, "public entrepreneurship, innovation" deepens the reform of higher education. The paper expounds how to cultivate talents with the integrated innovation for Information technology and law education. We put forward "Class and Competition" mode, "Class-Certification Integration" mode for training law students' information technology application ability, and thus improve the innovation consciousness, innovation, teamwork and entrepreneurial potential comprehensive ability in practice. Through teaching computer basic course, improve students' information technology innovation ability applied in field of law.
\end{abstract}

\section{Introduction}

Computer application ability training is an importation thing in talent cultivation of "One body Two things". Mutual combination of information technology and professional knowledge, cross penetration, generate new major has become an important aspect in the development of modern science and a growing point of new subjects. In the current new situation, "public entrepreneurship, innovation" deepens the reform of higher education. How to effectively promote the undergraduates in the era of "Internet+" and big data, information interdisciplinary professional more than one innovative business, play the computer application technology innovation and promotion role in the teaching reform practice, cultivate undergraduates' comprehensive ability of innovative consciousness, innovative potential, team cooperation, entrepreneurship practice, strongly promote undergraduates' computer creative design applied to interdisciplinary professional application field.

For decades, in China the higher education training goal of law is from cultivating "legal work cadres" upgrade to "integrated and applicable law talents". Legal education goal avoids to homogenizing. Along with the social development and progress of science and technology, especially the development marked by informationization, the digital science and technology, all put forward new request for law talent cultivation. The law talents should not only master the basic knowledge of law, but also the professional and technical knowledge, especially the knowledge of emerging science and technology. Emphasizes the combination of law and modern science and technology, and pay attention to the development of law talents.

Undergraduate Innovation and Entrepreneurship Training Program is the key project of the higher school undergraduate teaching quality and reform project. Aimed at promoting transformation of higher school education ideas, reform of talent training mode, strengthen the innovation ability training, enhance the innovative ability of undergraduates and on the basis of innovative entrepreneurial ability, cultivate high level innovation talents to satisfy the needs of the construction of an innovative country. So, every year our university held many times undergraduates' innovative entrepreneurial training program application and selection. Let more students participate in the creative activities. In 2015, our university East China University of Political Science and Law (ECUPL) organizes undergraduates' innovative training program. Internet + for work. The experts recommend 55 the projects. So far, in 2015 our university got 50 national projects, 182 provincial projects. 
In the future, our university will continue to promote the reform of innovation and entrepreneurship, continue to advance undergraduates' innovative entrepreneurial training project, update the education teaching idea, reform teaching methods, strengthen the innovation ability of students, build a better platform for the cultivation of innovative talents. The university will follow the frontier major development, adopt flexible and varied forms to encourage students to participate in undergraduates' innovation and entrepreneurship training programs, and improve the innovation ability and talent training quality.

College of politics and law is the law as the main body, combining other disciplines. After graduation, most of undergraduates are engaged in the work related to the law. Therefore how to open the computer course with characteristic of law in the university, prompting law major students in the class of computer application basic prossess a certain computer practical operation ability and innovation ability, is a project we have been discussed.

\section{“Class and Competition” Innovative Talents Training Mode}

"Class and Competition" Innovative talents training mode is from knowledge to ability, from the study to the application. It bases on a single course-computer application basic course, combining the curriculum and the competition, let law major students participate in the competition of information technology. The students can be push from passive to active learning skills of exploration and practice, and familiar with not only mastering the skill, but also having a wealth of practical experience, innovation, entrepreneurship and practice ability.

In 2012-2015, the construction cycle of law characteristics of computer course system, the computer teachers in our university through the unervsity's funding, the lead organization, the implementation of a series of reform measures, organized professional and non-professional students to participate in the national competition of information technology more than 20 times. The competitions included 2012 National Micromouse Competition, the 7th National Information Technology Application Proficiency Test, the 5th National college students' information security competition, the 5th "Blue Bridge Cup" national software and information technology professionals competition (final), the 2nd session of China college students games creative design contest the national finals, the 7th China undergraduate computer design contest, etc. The effective of "Class and Competition" mode of innovative talent training is obvious. Many teams emerged from nearly more than thousand teams in national wide, got prize and won the honor for the school.

Participating students said "Class and Competition" innovation talents training mode brought them more opportunities to hone, show themselves, from the course towards the competition, from theory to practice, from the campus to the country, pushing later development and learning. Teachers said they would further improve the mode, let more students benefit from it, and strive to achieve better results in the further competitons.

Effectively mobilize the students' learning interest and motivation, and also encourage students to master the knowledge more comprehensively and clearly. It will improve the students' vocational skills and information literacy. Build an interdisciplinary field of diversified talents training practice platform.

The goal of College computer competition is promoting the teaching reform under the new situation of education, expanding innovation technology exchange, improving the quality of innovative talent training, motivating college students through participating in activities such as technology innovation, application innovation, design innovation. Then stimulate students' innovative entrepreneurial enthusiasm, promote diversified innovative entrepreneurial talent training education teaching reform. In the new situation, cultivate new technology development and diversified college students' innovation ability training[2].

This mode reflects the major characteristics and the teaching goal of innovation practice, talents training quality. Use the competiton to promote major construction, teaching, and learning. 


\section{“Class-Certification Integration” Innovative Talents Training Mode}

Through teaching computer application basic course to help students pass the computer rank exam is an important part of computer teaching in our university. How to look rank examination as a guide, draw lessons from the aim and object of examination, reform unreasonable factors in the law character computer teaching, improve students' practical application ability and innovation ability, enhance students' ability of using computer methods to solve practical problems, has always been the key content of training talents in our university.

Shanghai College Computer Rank Examination is oragnized by Shanghai Municipal Education Commission, as one of the important basis of the detection and evaluation of computer application teaching level and teaching quality. The examination intended to regulate and strengthen the computer teaching for non-computer major students, and improved these students' computer application ability. Examination objects mainly are Shanghai non-computer major undergraduates, and contents include computer application basic knowledge, operating systems and office software, multimedia technology and computer networks. According to the undergraduate training plan in our university, all students must achieve the computer rank grade One. While the students according to their own development needs, spontaneously volunteer for the national computer rank grade Two.

National Computer Rank Examination grade Two includes language programming $(\mathrm{C}, \mathrm{C}++$, Java, Visual Basic, Web), database programming (Visual FoxPro, Access, MySQL), Office software (such as MS Office senior application), totally nine subjects.

The examination requires the participants to master a computer language, the optional categories are an advanced language programming, database programming, WEB programming, etc.. The exmination also includes Office software application ability. It requires the participants to have computer application knowledge and MS Office software advanced application ability, to carry out specific application in the practical Office environment.

The reform engage in organizing Computer program design course and the rank examination together. Try to let the rank examination fully play the incentive and guiding role. It Is conducive to further improve the level of our university computer teaching, and improve the influence of our university in the same college.

\section{Significant Innovation}

Through the computer application basic course with integrated innovation for information technology and law, greatly improve the students' practical application ability and innovation ability. In the unified organization of the university, the computer teachers, guided law major students to paricipate in many national or provincial computer application contest, then obtained the excellent result.

Table 1 Participated Competition Table

\begin{tabular}{|l|c|c|}
\hline & National Competition & Provincial Competition \\
\hline $2012-2015$ & 7 & 7 \\
\hline
\end{tabular}

During 2012 to 2015, the students in our university have participated in national or provincial information technology competitions, won national and provincial awards dozens of times. Some competition entries have law characteristics, such as "East China University of Political Science and Law dissemination network" web page design work, "East China University of Political Science and Law cases" web page design work, " Three Stricts and Three Steadies around me " multimedia work, "my China dream" multimedia work, "based on cloud storage automatic password input software design and implementation ", etc.

At the same time, our university has opened the unique characteristics of the law courses, for students to study. Such as 
Table 2 The law character information courses in ECUPL

\begin{tabular}{|l|}
\hline Name of Course \\
\hline $\begin{array}{l}\text { Computer Thinking and Computational } \\
\text { Culture }\end{array}$ \\
\hline $\begin{array}{l}\text { Information crime and Computer } \\
\text { forensics }\end{array}$ \\
\hline Software intellectual property protection \\
\hline The electronic government affairs \\
\hline $\begin{array}{l}\text { The government website construction and } \\
\text { management }\end{array}$ \\
\hline $\begin{array}{l}\text { The technology of electronic } \\
\text { reconnaissance }\end{array}$ \\
\hline Electronic evidence \\
\hline Information Law \\
\hline Judicial authentication \\
\hline
\end{tabular}

\section{Outlook: problems and thinking}

At present, our university foster talents understanding law and technology, in order to train compound talents. The traing target is the coordinated development of students' knowledge, ability and quality, by the idea of the computational thinking to cultivate students' proof and innovative spirit. Problem: according to the characteristics of law subject, how to enhance the integration of law and information technology cases teaching, in order to improve the students' ability to solve the problem? For the characteristics of curriculum integration technology principle and disciplines, how to draw lessons from the experience of the science and engineering laboratory teaching, integrate theory with practice? Thinking: in the practice teaching, make students apply related technical principle and the theoretical knowledge of law, to reflect, to explore the discipline intersection problems, comprehensively promote learning ability and practice ability. For some emerging diverse courses with law characteristics, can apply multidisciplinary joint teaching way.

\section{Acknowledgements}

This work was supported by Computer teaching reform project in Arts and Humanity Universities of Ministry of Education (No. 2014-A023).

\section{References}

[1] Zhang Li, Xie Baiqing, Song Xuming. The guiding role of Computer Competition in Cultivating Creative Interdisciplinary Talents. Computer Education. 2015(22):12-14,24.

[2] Xiong Zhihai, Chen Chunzhu. Exploration Legal Education Mode of Undergraduate in Science and Engineering Universities. Journal of Chongqing Unversity of Posts and Telecommunications (Social Science Edition). 2012(24)1:135-141.

[3] Liu Qin. Open Computer Basic Course with Law Character Relying on Major Teaching. Computer Education. 2009(10):45-47.

[4] Zhang Yanhong, Li Ying, Du Jing, Xing Cuifang. Reform on Computer Programming Teaching with Computer Rank Examination. Computer Education. 2015(6):41-43. 